\title{
Correction to: Pain management during labor: use of intermittent drug delivery devices for improvement of obstetric and neonatal outcome and reduction of healthcare burden: a large non-inferiority randomized clinical trial
}

Laura Rinaldi ${ }^{* *}$, Anna Maria Ghirardini ${ }^{1}$, Raffaella Troglio², Valentina Bellini ${ }^{2}$, Lara Donno ${ }^{1}$, Susanna Biondini ${ }^{2}$, Emanuela Biagioni ${ }^{1}$, Marco Baciarello ${ }^{2}$, Elena Bignami ${ }^{2}$ and Massimo Girardis ${ }^{1}$

Correction to: J Anesth Analg Crit Care 1, 2 (2021) https://doi.org/10.1186/s44158-021-00003-w

Following publication of the original article [1], the authors identified that the given names and family names of all authors were swapped.

The author group has been updated above and the original article has been corrected.

\section{Author details}

${ }^{1}$ Anesthesia and Intensive Care Unit, University Hospital of Modena, L.go del Pozzo 71, 41,125 Modena, Italy. ${ }^{2}$ Anesthesiology and Critical Care Division, Department of Medicine and Surgery, University of Parma, Viale Gramsci 14, 43,126 Parma, Italy.

Published online: 25 October 2021

\section{Reference}

1. Rinaldi L, Ghirardini AM, Troglio R et al (2021) Pain management during labor: use of intermittent drug delivery devices for improvement of obstetric and neonatal outcome and reduction of healthcare burden: a large non-inferiority randomized clinical trial. J Anesth Analg Crit Care 1(1):2. https://doi.org/10.1186/s44158-021-00003-w

* Correspondence: rinaldi.laura@unimore.it

'Anesthesia and Intensive Care Unit, University Hospital of Modena, L.go del Pozzo 71, 41,125 Modena, Italy

Full list of author information is available at the end of the article

(c) The Author(s). 2021 Open Access This article is licensed under a Creative Commons Attribution 4.0 International License, which permits use, sharing, adaptation, distribution and reproduction in any medium or format, as long as you give appropriate credit to the original author(s) and the source, provide a link to the Creative Commons licence, and indicate if changes were made. The images or other third party material in this article are included in the article's Creative Commons licence, unless indicated otherwise in a credit line to the material. If material is not included in the article's Creative Commons licence and your intended use is not permitted by statutory regulation or exceeds the permitted use, you will need to obtain permission directly from the copyright holder. To view a copy of this licence, visit http://creativecommons.org/licenses/by/4.0/. 